\title{
The Development of Authentic Assessment Instruments on Drama Text Learning for Students of Class VIII in Junior High School 6 Tebing Tinggi
}

\author{
Yanti Gultom $^{1}$, Biner Ambarita ${ }^{2}$, Syahnan Daulay ${ }^{2}$ \\ ${ }^{1}$ Master Student in State University of Medan (Unimed), Medan, Indonesia \\ ${ }^{2}$ Lecturer in State University of Medan (Unimed), Medan, Indonesia \\ yantigulatomat@yahoo.co.id
}

\begin{abstract}
This study aims to know the development of authentic assessment instruments on drama text learning for students of class VIII in Junior High School 6 Tebing Tinggi. This study used random sampling. The sample were 32 student and 3 teacher. The quality of authentic assessment instruments in drama text learning is obtained from the results of validation and assessment given by material experts, expert evaluations, teacher responses, and student responses. The result shows that the average value of the student's pretest was 68.56. Based on the average value of the student pretest data, it can be concluded that the ability of students does not experience a significant high increase and has not reached KKM. Learning by using authentic assessment instruments on drama text learning gained an average of 80.97. The lowest student score is 70 and the highest was 98. Based on the average value of student posttest data, it can be concluded that the ability of students to experience a significant increase was high and reaches KKM as expected. The effectiveness of the assessment instrument developed was $80.97 \%$ and the effectiveness before using the valuation instrument was $68.56 \%$. Therefore, the level of students' ability to answer drama text questions increases after the product of authentic assessment instruments in drama text learning was applied in learning.

Keywords : authentic assessment instruments; drama text learning; student.
\end{abstract}

\section{Introduction}

The curriculum is very influential on the development of learning. The curriculum consists of Competency Standards and Basic Competencies which are the reference standards of ability that must be mastered by students. In this regard, competence is demonstrated by students through performance in the learning process.

The curriculum according to Law No. 20 of 2003 concerning the National Education System. "In the Law it is stated that the curriculum is a set of plans and arrangements regarding the content and material of the lesson as well as the methods used as guidelines for the implementation of teaching and learning activities". The curriculum is a container that will determine the direction of education. The success of an education depends on the curriculum used.

Starting in July 2013, the government has enacted a new curriculum called the 2013 Curriculum. The enactment of the 2013 curriculum emphasizes activity-based learning, so the assessment places more emphasis on process assessment both on aspects of attitudes, knowledge, and skills. Curriculum, learning process, and assessment of learning processes and outcomes are important components in learning activities. These components are interrelated with one another.

The learning process is an effort to achieve Basic Competencies formulated in the curriculum. Meanwhile, assessment activities are carried out to measure and assess the level of achievement of Basic Competence. Assessment is also used to determine the strengths and weaknesses in the learning process, so that it can be used as a basis for decision making, and improvement of the learning process that has been done. Therefore, a good curriculum and the 
correct learning process need to be supported by a good, planned and sustainable assessment system.

Authentic assessment is a distinctive feature of the 2013 Curriculum. Authentic assessment is a comprehensive assessment to assess the input, process, and output of learning. Authentic assessment must reflect real-world problems, not the school world. Using a variety of holistic methods and criteria (full competence reflects knowledge, skills and attitudes).

\section{Review of Literatures}

\subsection{Authentic Assessment Instruments}

Assessment of learning processes and learning results is an integral part of the planning and implementation of the teacher's learning process. Assessment of learning in the 2013 Curriculum is directed at authentic assessment. In simple authentic assessment is often referred to as authentic assessment. Supardi (2015: 24) revealed that authentic assessment is one of the assessment of learning outcomes that requires students to show achievements and learning outcomes in the form of real-life abilities in the form of performance or work results.

More broadly, authentic assessment is defined as a comprehensive assessment to assess the input, process and output. Authentic assessment is done to measure attitudes, knowledge and skills competencies.

Permendiknas Number 66 of 2013 outlines the assessment of attitude competencies carried out through observation, self-assessment, and assessment of "peers" (peer evaluations) by students and journals. The instrument used for observation, self-assessment, and assessment among students is a checklist or rating scale accompanied by a rubric, while the journal is in the form of educator's notes. Furthermore, it was stated by educators to assess knowledge competencies through written tests, oral tests, and assignments. Whereas skills competency through performance assessment, namely assessment that requires students to demonstrate a particular competency using practical tests, projects, and portfolio assessments. The instrument used is in the form of a checklist or rating scale equipped with a rubric. Furthermore, Sani (2016: 23) says that authentic assessment is a type of assessment that directs students to demonstrate the skills and competencies needed to overcome problems and situations encountered in the real world.

\subsection{Drama}

Drama is one of the literary works that presents a storyline with the actors who are in charge of conveying the whole story. Endraswara, (2011: 264) says that drama or theater are performances that occur in the human world. The performers of course are human beings who are good at boarding. Mastering means being good at polishing situations, can be oily in water, can express what is not real, and imaginative. Furthermore, Rosmawaty (2011: 51) explains that drama is a collective work coordinated by the director, namely theater work with the skills and expertise to lead the actresses and technical workers in the performance.

In line with the above, Kosasih (2012: 132), explained the meaning of drama as a form of literary work aimed at describing life by conveying conflict and emotion through conduct and dialogue. Drama becomes a medium in describing imagination based on sensations that have been obtained from the dynamics of the reality of human life. Dialogue on drama scripts is a medium in describing stories. 
Some of the meanings above, it can be concluded that drama is a literary work that depicts daily life by conveying the conduct and emotions and character of the actor through staged behavior or dialogue.

\subsection{Classification of Figures}

Characterization is closely related to disposition. The character's figure will be seen in the dialogue and instructions for acting or side instructions. The type and color of the dialogue shows the character of the character. Based on the role of the story there are protagonists, antagonists, and tritagonists. The protagonist is a character who supports the story. This main character is usually assisted by other figures involved in the story. An antagonist, is a character who opposes the story. Usually there is one antagonist and some of his helpers who oppose the story. Tritagonist figure is a supporting character, both for the protagonist and for the antagonist.

Based on their roles and functions in the play, there is a central figure. The main character, and the supporting character. Central figures are the most decisive figures in the play, main characters, opponents and supporters of central figures. Helper figures, namely figures who hold complementary or additional roles in the series of stories. For example, grandfather is the central figure in the drama Nol / RW Nol RT, while the main characters are Ani and Ina. While the supporting figures are Tompel, Babah Liem, and Limp. The classification of characters in the drama is marked by the number of dialogues written by the author.

\section{Research Methods}

The study was conducted at Junior High School 6 Tebing Tinggi, located on Gatot Subroto Street Km 5, Tebing Tinggi. The study was conducted in even semester of 2018/2019 Learning Year. Data and data sources of this study were teachers and eighth grade students of Junior High School 6 Tebing Tinggi. Looking at the effectiveness of the product which being developed, the researcher only takes samples using random sampling techniques, or random samples, or mixed samples. The researcher took a sample of 32 students and 3 teachers.

\section{Discussion}

The process of developing authentic assessment instruments for drama text learning is carried out in several stages, namely preliminary studies, initial product development, and product trials.

Table 1. Data Need Analysis

\begin{tabular}{|l|l|l|l|l|l|l|}
\hline \multirow{2}{*}{ No } & \multirow{2}{*}{ Question } & \multirow{2}{*}{ Answer } & \multicolumn{4}{|l|}{ Frequency } \\
\cline { 3 - 7 } & & Teacher & $\%$ & Student & $\%$ \\
\hline 1. & $\begin{array}{l}\text { Get to know or know the } \\
\text { authentic assessment } \\
\text { instruments }\end{array}$ & Yes & 2 & $66,7 \%$ & 3 & $9,4 \%$ \\
\cline { 2 - 7 } 2. & $\begin{array}{l}\text { Using authentic } \\
\text { assessment instruments in } \\
\text { drama text learning } \\
\text { activities }\end{array}$ & Yes & 0 & $33,3 \%$ & 29 & $\begin{array}{l}90,6 \\
\%\end{array}$ \\
\cline { 2 - 7 } & & 3 & $100 \%$ & 32 & $100 \%$ \\
\hline
\end{tabular}




\begin{tabular}{|l|l|l|l|l|l|l|}
\hline 3. & $\begin{array}{l}\text { Requires authentic } \\
\text { assessment instruments } \\
\text { specifically developed in } \\
\text { drama text learning } \\
\text { material }\end{array}$ & Yes & 3 & $100 \%$ & 26 & $\begin{array}{l}81,3 \\
\%\end{array}$ \\
\cline { 2 - 7 } & & 0 & $0 \%$ & 6 & $\begin{array}{l}18,7 \\
\%\end{array}$ \\
\hline
\end{tabular}

Based on the table above it is known that some Indonesian language teachers of Junior High School 6 Tebing Tinggi (66.7\%) stated that they knew authentic assessment instruments, while 29 students or $90.6 \%$ of the total students stated that they did not know authentic assessment instruments. All teachers and students (100\%) stated that they had never used authentic assessment in drama text learning activities developed in the learning process. All teachers $(100 \%)$ stated that they needed authentic assessment instruments specifically developed in drama text learning material developed in accordance with the 2013 curriculum in the learning process and 26 students or $81.3 \%$ of the total students stated that they needed authentic assessment instruments specifically developed on the material drama text learning developed in the learning process.

The cover is designed according to the characteristics of the text used in product development that is drama text. The drama text has three dimensions, namely writing (literature), movement, and speech. Movement in this case is the gesture and expression of the character when playing a role in the drama. There are two faces like masks that can be interpreted as expressions on the cover of the product being developed. First, facial expressions express sadness like the expression of a drama character who plays a sad role in the drama. Secondly, facial expressions express happiness like the expression of a drama character who plays a happy role in drama. The color of the cover only consists of three colors, namely black, white, and red. The cover also contains the title of the appraisal device contents, the identity of the author, and the identity of the supervisor. The cover image can be seen below.

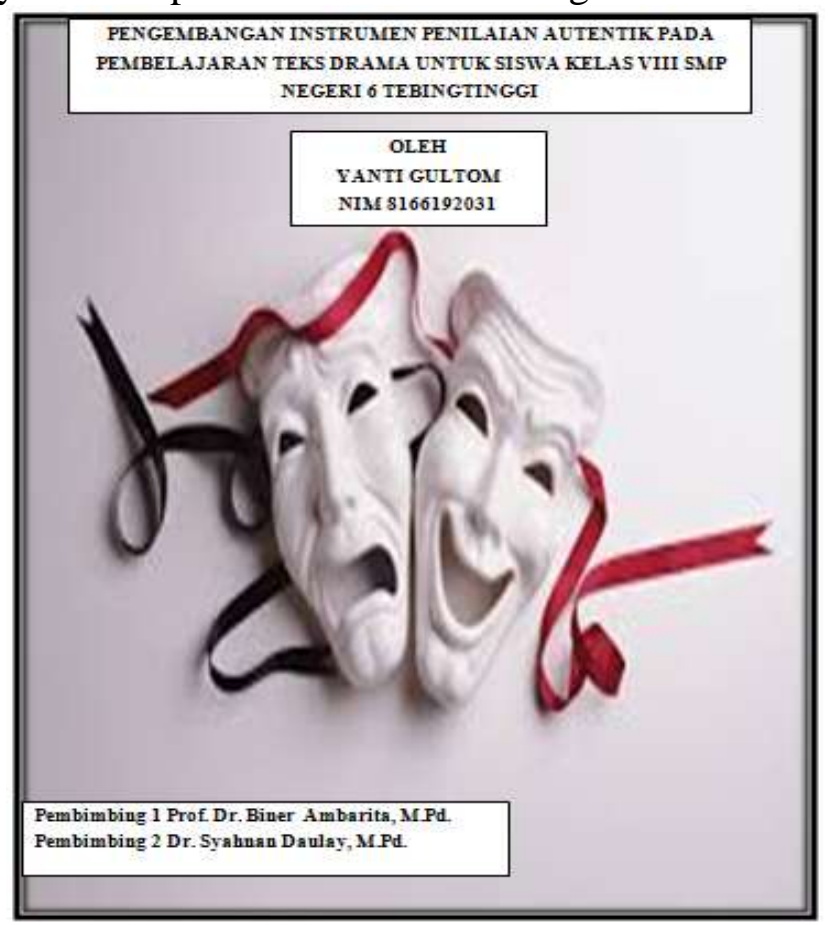

Figure 1 Cover of the Assessment Instrument 
The number of multiple choice test questions on the product is ten questions in each basic competency. Authentic assessment instruments in drama text learning developed have four basic competencies in drama text learning; KD 3.15, KD 4.15, KD 3.16, and KD 4.16. Therefore, there are forty multiple choice tests in the assessment instrument. The description of multiple choice questions can be seen below.

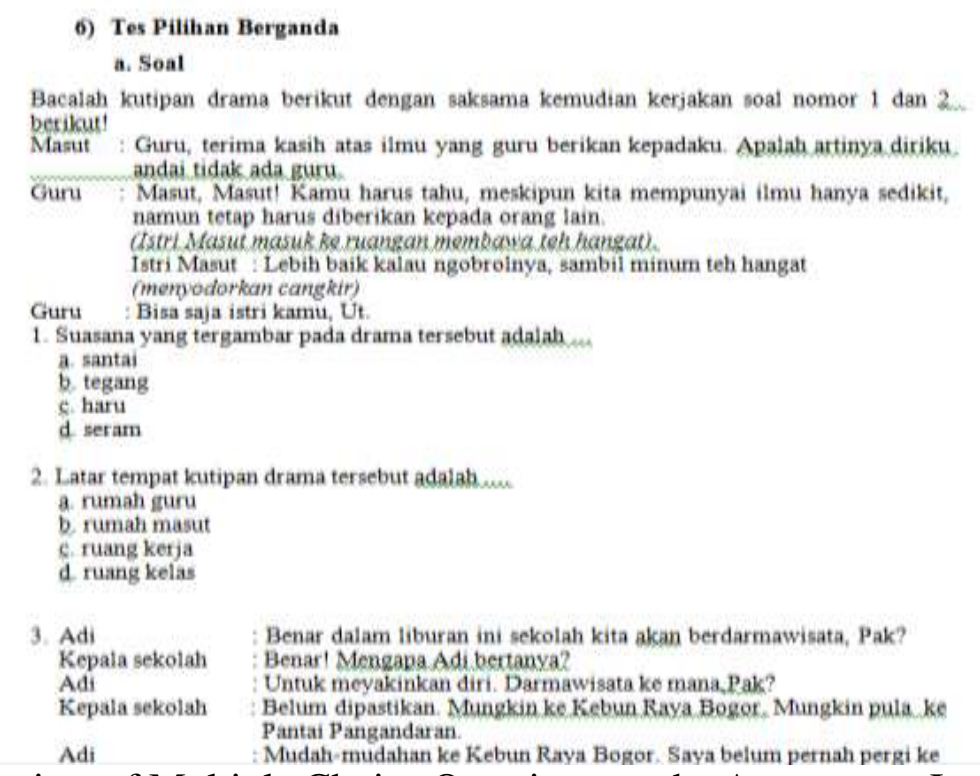

Figure 4. Overview of Multiple Choice Questions on the Assessment Instrument

Knowledge assessment instruments that can be used by the teacher are written tests and assignment tests. Written essay tests are done by referring to the drama text that has been provided. Five questions that are made cannot be separated from the drama text. The description of the drama text and questions from written essays can be seen below.

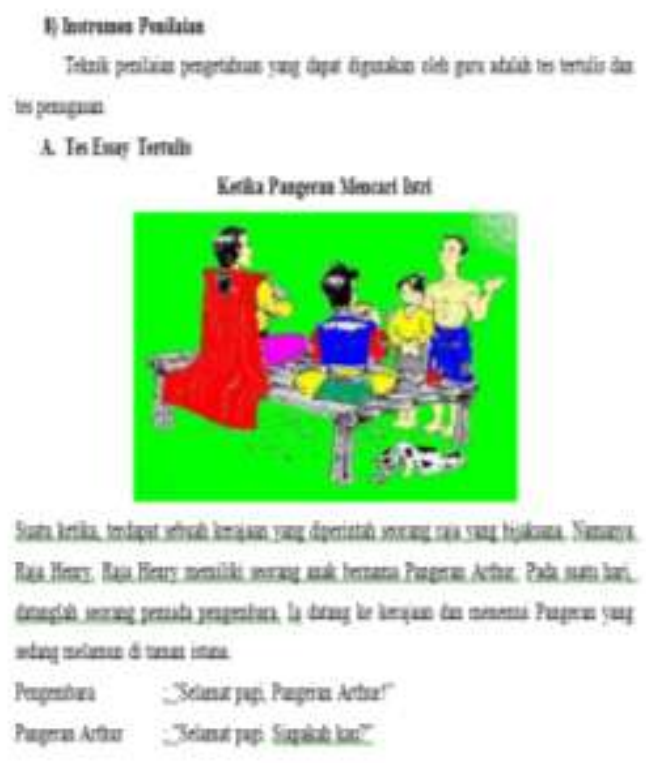

Figure 5. The Written Essay Test

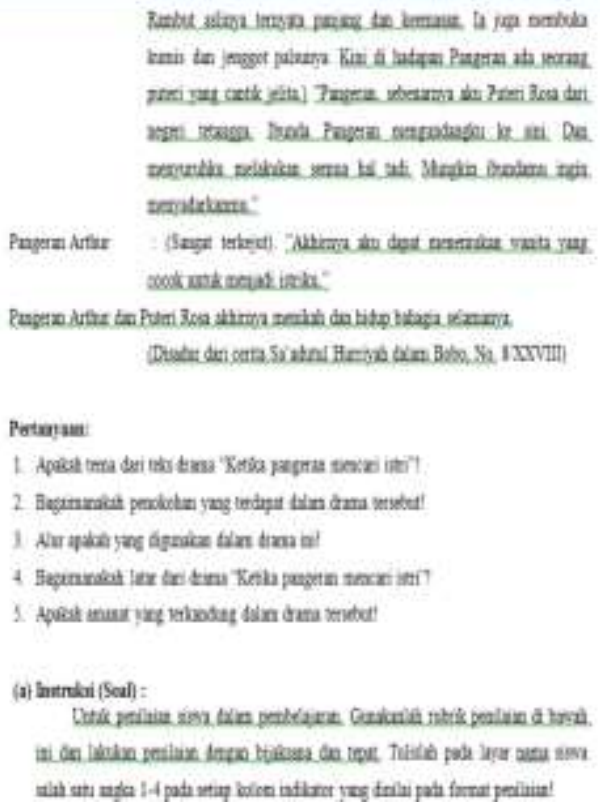


Table 2. Validity of Multiple Choice Tools

\begin{tabular}{|c|c|c|c|}
\hline Question number & rtable & $\mathbf{r}_{\text {count }}$ & Information \\
\hline 1 & 0,423 & 0,67 & Valid \\
\hline 2 & 0,423 & 0,72 & Valid \\
\hline 3 & 0,423 & 0,65 & Valid \\
\hline 4 & 0,423 & 0,55 & Valid \\
\hline 5 & 0,423 & 0,67 & Valid \\
\hline 6 & 0,423 & 0,58 & Valid \\
\hline 7 & 0,423 & 0,74 & Valid \\
\hline 8 & 0,423 & 0,44 & Valid \\
\hline 9 & 0,423 & 0,58 & Valid \\
\hline 10 & 0,423 & 0,60 & Valid \\
\hline 11 & 0,423 & 0,43 & Valid \\
\hline 12 & 0,423 & 0,44 & Valid \\
\hline 13 & 0,423 & 0,56 & Valid \\
\hline 14 & 0,423 & 0,53 & Valid \\
\hline 15 & 0,423 & 0,47 & Valid \\
\hline 16 & 0,423 & 0,53 & Valid \\
\hline 17 & 0,423 & 0,58 & Valid \\
\hline 18 & 0,423 & 0,58 & Valid \\
\hline 19 & 0,423 & 0,53 & Valid \\
\hline 20 & 0,423 & 0,72 & Valid \\
\hline 21 & 0,423 & 0,72 & Valid \\
\hline 22 & 0,423 & 0,45 & Valid \\
\hline 23 & 0,423 & 0,14 & Invalid \\
\hline 24 & 0,423 & 0,56 & Valid \\
\hline 25 & 0,423 & 0,17 & Invalid \\
\hline 26 & 0,423 & 0,61 & Valid \\
\hline 27 & 0,423 & 0,71 & Valid \\
\hline 28 & 0,423 & 0,66 & Valid \\
\hline 29 & 0,423 & 0,71 & Valid \\
\hline 30 & 0,423 & 0,88 & Valid \\
\hline 31 & 0,423 & 0,29 & Invalid \\
\hline 32 & 0,423 & 0,69 & Valid \\
\hline 33 & 0,423 & 0,70 & Valid \\
\hline 34 & 0,423 & 0,83 & Valid \\
\hline 35 & 0,423 & 0,42 & Valid \\
\hline 36 & 0,423 & 0,46 & Valid \\
\hline 37 & 0,423 & 0,70 & Valid \\
\hline 38 & 0,423 & 0,89 & Valid \\
\hline 39 & 0,423 & 0,72 & Valid \\
\hline 40 & 0,423 & 0,71 & Valid \\
\hline 41 & 0,423 & 0,71 & Valid \\
\hline 42 & 0,423 & 0,53 & Valid \\
\hline
\end{tabular}




\begin{tabular}{|l|l|l|l|}
\hline 43 & 0,423 & 0,80 & Valid \\
\hline 44 & 0,423 & 0,89 & Valid \\
\hline 45 & 0,423 & 0,70 & Valid \\
\hline 46 & 0,423 & 0,89 & Valid \\
\hline 47 & 0,423 & 0,29 & Invalid \\
\hline 48 & 0,423 & 0,22 & Invalid \\
\hline 49 & 0,423 & 0,89 & Valid \\
\hline 50 & 0,423 & 0,36 & Invalid \\
\hline
\end{tabular}

From the table above it can be seen that 44 items are in the valid level and 6 items are invalid. This concerns the rules of validity, i.e. If $r_{\text {count }}>r_{\text {table }}$, the item is valid and if $r_{\text {count }}<r_{\text {table, }}$ the item is invalid. Therefore, 15 items can be used because there are valid criteria.

Table 3. The Validity of Description Form Instruments

\begin{tabular}{|c|c|c|c|}
\hline Question number & rtable & $\mathbf{r}_{\text {count }}$ & Information \\
\hline 1 & \multirow{10}{*}{0,423} & 0,54 & Valid \\
\hline 2 & & 0,38 & Invalid \\
\hline 3 & & 0,28 & Invalid \\
\hline 4 & & 0,29 & Invalid \\
\hline 5 & & 0,58 & Valid \\
\hline 6 & & 0,09 & Invalid \\
\hline 7 & & 0,45 & Valid \\
\hline 8 & & 0,48 & Valid \\
\hline 9 & & 0,56 & Valid \\
\hline 10 & & 0,42 & Valid \\
\hline
\end{tabular}

From the table above shows that 6 items of description are at the valid level and 4 items are invalid. This refers to the rules of validity, i.e. If $r$ count $>r$ table, the item is valid and if $r_{\text {count }}<r_{\text {table }}$, the item is invalid. Therefore 6 items can be used because they are valid criteria.

Different test power tests separate smart students and less intelligent students to know the level of goodness of each item. Different power criteria are $0.00<D<0.20$ : bad, $0.21<D$ <0.40: enough, $0.41<\mathrm{D}<0.70$ : good, $0.71<\mathrm{D}<1.00$ : very good. Based on the calculation of the different power in the attachment that 4 questions have different power on sufficient criteria (the question is revised), 3 questions on the criteria are good (the question is accepted), and 3 questions in the criteria are bad (rejected).

Difficulty level test aims to capture subjects who answer test items correctly. The criteria for difficulty level are $0.00<\mathrm{P}<0.30$ : too difficult, $0.30<\mathrm{p}<0.70$ : moderate, and $0.70<\mathrm{p}<1.00$ : too easy. Based on the calculation of the level of difficulty in the appendix, it can be seen that 5 questions have the criteria of the level of difficulty "easy" which means the question is accepted. Questions that have the criteria of "moderate" difficulty level are 5 questions. Some questions have moderate or easy and invalid criteria, so the question is not used. Based on these categories 2 questions have criteria for "invalid" validity and medium difficulty criteria. Therefore, 2 the matter is discarded / not used.

The expert instrument assessment material validates the product that has been developed. Validation of the assessment instrument material was carried out by Prof. Amrin Saragih, MA, And Dr. Shafwan Hadi Umry, M. Hum., who are the lecturer at Medan State University. The 
assessment of the assessment instrument material was carried out to improve the quality of the material in the assessment instruments developed. Product validation is carried out until it meets the criteria valid / feasible to be used in the field according to the validator.

The data from the expert validation of the material for authentic assessment instruments in drama text learning by validator I are Prof. Amrin Saragih, MA., Can be seen in the table below:

Table 4. The Results of Validation of Assessment Instruments by Material Expert I

\begin{tabular}{|c|c|c|c|c|}
\hline No & Component & Indicator & $\begin{array}{l}\text { Average } \\
(\%)\end{array}$ & Criteria \\
\hline \multirow{4}{*}{1} & \multirow{4}{*}{$\begin{array}{l}\text { Aspect of } \\
\text { Content } \\
\text { Feasibility }\end{array}$} & $\begin{array}{l}\text { Compatibility of material } \\
\text { with KI and KD }\end{array}$ & $100 \%$ & Very Good \\
\hline & & Content accuracy & $100 \%$ & Very Good \\
\hline & & Material proficiency & $100 \%$ & Very Good \\
\hline & & Encourage curiosity & $100 \%$ & Very Good \\
\hline \multicolumn{3}{|c|}{ Average Number of Indicators } & $100 \%$ & Very Good \\
\hline \multirow{5}{*}{2} & \multirow{5}{*}{$\begin{array}{l}\text { Language } \\
\text { Feasibility } \\
\text { Aspects }\end{array}$} & Straightforward & $100 \%$ & Very Good \\
\hline & & Communicative & $100 \%$ & Very Good \\
\hline & & Dialogical and interactive & $75 \%$ & Good \\
\hline & & $\begin{array}{l}\text { Conformity with the } \\
\text { development of students }\end{array}$ & $100 \%$ & Very Good \\
\hline & & Conformity with language rules & $100 \%$ & Very Good \\
\hline \multicolumn{3}{|c|}{ Average Number of Indicators } & $95 \%$ & Very Good \\
\hline \multirow{4}{*}{3} & \multirow{4}{*}{$\begin{array}{l}\text { Aspects of } \\
\text { Feasibility } \\
\text { of } \\
\text { Presentation }\end{array}$} & Presentation technique & $100 \%$ & Very Good \\
\hline & & Presentation support & $75 \%$ & Good \\
\hline & & Presentation of learning & $100 \%$ & Very Good \\
\hline & & $\begin{array}{l}\text { Coherence and chaos of } \\
\text { thought }\end{array}$ & $100 \%$ & Very Good \\
\hline \multicolumn{3}{|c|}{ Average Number of Indicators } & $94 \%$ & Very Good \\
\hline \multicolumn{3}{|c|}{ Average Amount of All Sub Components } & $96,33 \%$ & Very Good \\
\hline
\end{tabular}

Table 5. The Percentage of Assessment from Materials I

\begin{tabular}{|l|l|l|l|}
\hline No & Sub Component of Assessment & Average (\%) & Criteria \\
\hline 1 & Content Feasibility & $100 \%$ & Very Good \\
\hline 2 & Language Feasibility & $95 \%$ & Very Good \\
\hline 3 & Feasibility of Presentation & $94 \%$ & Very Good \\
\hline \multicolumn{2}{|l}{ Average } & $\mathbf{9 6 , 3 3 \%}$ & Very Good \\
\hline
\end{tabular}

The data from the expert validation of the material for authentic assessment instruments on drama text learning by validator II were Dr. Shafwan Hadi Umry, M.Hum., Can be seen in the table below. 
Table 6. The Results of Assessment Instrument Validation by Material Expert II

\begin{tabular}{|c|c|c|c|c|}
\hline No & Component & Indicator & $\begin{array}{l}\text { Average } \\
(\%)\end{array}$ & Criteria \\
\hline \multirow{4}{*}{1} & \multirow{4}{*}{$\begin{array}{l}\text { Aspect of } \\
\text { Content } \\
\text { Feasibility }\end{array}$} & $\begin{array}{l}\text { Compatibility of material } \\
\text { with KI and KD }\end{array}$ & $75 \%$ & Good \\
\hline & & Content accuracy & $75 \%$ & Good \\
\hline & & Material proficiency & $75 \%$ & Good \\
\hline & & Encourage curiosity & $75 \%$ & Good \\
\hline \multicolumn{3}{|c|}{ Average Number of Indicators } & $75 \%$ & Good \\
\hline \multirow{5}{*}{2} & \multirow{5}{*}{$\begin{array}{l}\text { Language } \\
\text { Feasibility } \\
\text { Aspects }\end{array}$} & Straightforward & $75 \%$ & Good \\
\hline & & Communicative & $75 \%$ & Good \\
\hline & & Dialogical and interactive & $75 \%$ & Good \\
\hline & & $\begin{array}{l}\text { Conformity with the } \\
\text { development of students }\end{array}$ & $75 \%$ & Good \\
\hline & & Conformity with language rules & $75 \%$ & Good \\
\hline \multicolumn{3}{|c|}{ Average Number of Indicators } & $\mathbf{7 5 \%}$ & Good \\
\hline \multirow{4}{*}{3} & \multirow{4}{*}{$\begin{array}{l}\text { Aspects of } \\
\text { Feasibility } \\
\text { of } \\
\text { Presentation }\end{array}$} & Presentation technique: & $100 \%$ & Very Good \\
\hline & & Presentation support & $75 \%$ & Good \\
\hline & & Presentation of learning & $100 \%$ & Very Good \\
\hline & & $\begin{array}{l}\text { Coherence and chaos of } \\
\text { thought }\end{array}$ & $75 \%$ & Good \\
\hline \multicolumn{3}{|c|}{ Average Number of Indicators } & $\mathbf{8 8 \%}$ & Very Good \\
\hline \multicolumn{3}{|c|}{ Average Amount of All Sub Components } & $79,33 \%$ & Good \\
\hline
\end{tabular}

Table 7. The Percentage of Assessment for Each Sub Component of Material Expert II

\begin{tabular}{|l|l|l|l|}
\hline No & Sub Component of Assessment & Average (\%) & Criteria \\
\hline 1 & Content Feasibility & $75 \%$ & Good \\
\hline 2 & Language Feasibility & $75 \%$ & Good \\
\hline 3 & Presentation Feasibility & $88 \%$ & Very Good \\
\hline Average & $\mathbf{7 9 , 3 3 \%}$ & Good \\
\hline
\end{tabular}

Data from the expert validation of the assessment instrument by validators I and II, namely Prof. Amrin Saragih, MA., And Dr. Shafwan Hadi Umry, M.Hum. In detail can be seen in the attachment. The percentage results of each indicator can be seen in the table below.

Table 8. The Percentage of Assessment for Each Sub Component of Material Experts I and II

\begin{tabular}{|c|c|c|c|c|c|c|}
\hline \multirow{2}{*}{ No } & \multirow{2}{*}{$\begin{array}{l}\text { Sub Component of } \\
\text { Assessment }\end{array}$} & \multicolumn{2}{|c|}{ Respondent } & \multirow{2}{*}{$\begin{array}{l}\text { Total } \\
\text { score }\end{array}$} & \multirow{2}{*}{$\begin{array}{l}\text { Average } \\
(\%)\end{array}$} & \multirow{2}{*}{ Criteria } \\
\hline & & 1 & 2 & & & \\
\hline 1 & Content Feasibility & 16 & 12 & 28 & $87,5 \%$ & Very Good \\
\hline 2 & Language Feasibility & 19 & 15 & 34 & $85 \%$ & Very Good \\
\hline 3 & $\begin{array}{l}\text { Presentation } \\
\text { Feasibility }\end{array}$ & 15 & 14 & 29 & $94 \%$ & Very Good \\
\hline
\end{tabular}




\section{Total score \\ 50 \\ 41 \\ 91 \\ $\mathbf{8 8 , 8 3 \%}$ \\ Very Good}

Evaluation experts for assessment instruments are Prof. Dr. Paningkat Siburian, M.Pd. which is a validator I. Data from the results of validation by experts evaluating the quality of the assessment instruments developed can be seen in the table below.

Table 9. The Results of Validation of Assessment Instruments by Evaluation Experts I

\begin{tabular}{|c|c|c|c|}
\hline No & Indicators & Average & Criteria \\
\hline & A. Conformity of material with basic competencies & $94 \%$ & $\begin{array}{l}\text { Very } \\
\text { Good }\end{array}$ \\
\hline 1 & $\begin{array}{l}\text { The material in the authentic assessment instrument is in } \\
\text { accordance with the specified SK and KD }\end{array}$ & $100 \%$ & $\begin{array}{l}\text { Very } \\
\text { Good }\end{array}$ \\
\hline 2 & $\begin{array}{l}\text { Material relevant to competencies that must be mastered } \\
\text { by students }\end{array}$ & $100 \%$ & $\begin{array}{l}\text { Very } \\
\text { Good }\end{array}$ \\
\hline 3 & $\begin{array}{l}\text { The accuracy of the unit title with the description of the } \\
\text { material in each section }\end{array}$ & $100 \%$ & $\begin{array}{l}\text { Very } \\
\text { Good }\end{array}$ \\
\hline \multirow[t]{2}{*}{4} & $\begin{array}{l}\text { The level of difficulty and complexity of the material is } \\
\text { adjusted to students' thinking abilities }\end{array}$ & $75 \%$ & Good \\
\hline & $\begin{array}{l}\text { B. Presenting competencies that must be mastered by } \\
\text { students }\end{array}$ & $\mathbf{8 8 \%}$ & $\begin{array}{l}\text { Very } \\
\text { Good }\end{array}$ \\
\hline 5 & $\begin{array}{l}\text { Competencies to be achieved are presented in authentic } \\
\text { assessment instruments }\end{array}$ & $100 \%$ & $\begin{array}{l}\text { Very } \\
\text { Good }\end{array}$ \\
\hline \multirow[t]{2}{*}{6} & Accuracy of learning objectives & $75 \%$ & Good \\
\hline & C. Material accuracy & $94 \%$ & $\begin{array}{l}\text { Very } \\
\text { Good }\end{array}$ \\
\hline 7 & $\begin{array}{l}\text { The material presented is in accordance with scientific } \\
\text { truth }\end{array}$ & $100 \%$ & $\begin{array}{l}\text { Very } \\
\text { Good }\end{array}$ \\
\hline 8 & $\begin{array}{l}\text { The depth of material is in accordance with the level of } \\
\text { development of students }\end{array}$ & $100 \%$ & $\begin{array}{l}\text { Very } \\
\text { Good }\end{array}$ \\
\hline 9 & $\begin{array}{l}\text { Conformity between basic competencies and learning } \\
\text { objectives }\end{array}$ & $100 \%$ & $\begin{array}{l}\text { Very } \\
\text { Good }\end{array}$ \\
\hline \multirow[t]{2}{*}{10} & $\begin{array}{l}\text { Appropriateness of grading assessment with the type of } \\
\text { assessment of skill aspects in each sub-theme } \\
\text { (demanding deed tests) }\end{array}$ & $75 \%$ & Good \\
\hline & D. Authentic Assessment & $90 \%$ & $\begin{array}{l}\text { Very } \\
\text { Good }\end{array}$ \\
\hline 11 & $\begin{array}{l}\text { Appropriate assessment in measuring attitude } \\
\text { competency }\end{array}$ & $100 \%$ & $\begin{array}{l}\text { Very } \\
\text { Good }\end{array}$ \\
\hline 12 & $\begin{array}{l}\text { Appropriate assessment in measuring knowledge } \\
\text { competencies }\end{array}$ & $100 \%$ & $\begin{array}{l}\text { Very } \\
\text { Good }\end{array}$ \\
\hline 13 & Appropriate assessment in measuring skill competency & $75 \%$ & Good \\
\hline 14 & Assessment encourages students to think critically. & $100 \%$ & $\begin{array}{l}\text { Very } \\
\text { Good }\end{array}$ \\
\hline
\end{tabular}




\begin{tabular}{|l|l|l|l|}
15 & $\begin{array}{l}\text { Assessment instruments can collect all student } \\
\text { assessment data on drama text learning material. }\end{array}$ & $75 \%$ & Good \\
\hline 16 & $\begin{array}{l}\text { Assessment instruments can be carried out during the } \\
\text { learning process. }\end{array}$ & $100 \%$ & $\begin{array}{l}\text { Very } \\
\text { Good }\end{array}$ \\
\hline 17 & $\begin{array}{l}\text { Assessment instruments access understanding and } \\
\text { critical thinking }\end{array}$ & $75 \%$ & Good \\
\hline 18 & $\begin{array}{l}\text { Assessment instruments are relevant to basic } \\
\text { competencies and core competencies }\end{array}$ & $100 \%$ & $\begin{array}{l}\text { Very } \\
\text { Good }\end{array}$ \\
\hline 19 & $\begin{array}{l}\text { Instrument for assessment in accordance with the } \\
\text { material taught }\end{array}$ & $\begin{array}{l}\text { Very } \\
\text { Good }\end{array}$ \\
\hline 20 & $\begin{array}{l}\text { The assessment is consistent with having accurate } \\
\text { scoring guidelines }\end{array}$ & $75 \%$ & Good \\
\hline Average Amount of All Sub Components & $\begin{array}{l}\text { Very } \\
\text { Good }\end{array}$ \\
\hline
\end{tabular}

The Evaluation Expert assessed that the test instruments and material on the product of authentic assessment instruments in drama text learning developed had an average percentage score of $91.5 \%$ with the criteria of "very good". The average percentage results are obtained based on the sub-component of material suitability with basic competencies, presenting competencies that must be mastered by students, material accuracy, and authentic assessment. The percentage results of each sub-component can be seen in the table below.

Table 10. The Percentage of Assessment for Each Sub Component of Evaluation Expert I

\begin{tabular}{|l|l|l|l|}
\hline No & Sub Component & Average (\%) & Criteria \\
\hline 1 & $\begin{array}{l}\text { Compatibility of material with } \\
\text { basic competencies }\end{array}$ & $94 \%$ & Very Good \\
\hline 2 & $\begin{array}{l}\text { Presenting competencies that must } \\
\text { be mastered by students }\end{array}$ & $88 \%$ & Very Good \\
\hline 3 & Material accuracy & $94 \%$ & Very Good \\
\hline 4 & Authentic assessment & $90 \%$ & Very Good \\
\hline Average & $\mathbf{9 1 , 5 \%}$ & Very Good \\
\hline
\end{tabular}

The results of expert evaluation validation for the assessment instrument in the subcomponent of material suitability with basic competencies had an average percentage of $94 \%$ with the criteria of "very good". The sub component presents competencies that must be mastered by students having an average percentage of $88 \% \%$ with the criteria of "very good". Sub-component of material accuracy has an average percentage of $94 \%$ with the criteria of "very good". The sub component of authentic assessment has an average percentage of $90 \%$ with the criteria of "very good". The average percentage of all sub-components is $91.5 \%$ with the criteria of "very good". This means that the authentic assessment instrument in drama text learning developed has good quality worthy of being tested on the field without revisions from the validator.

The evaluation expert for the assessment instrument is Dr. Surya Masniari Hutagalung, S.Pd., M.Pd. which is a validator II. Data from the validation results by experts evaluating the quality of the assessment instruments developed can be seen in the table below. 
Table 11. The Results of Validation of Assessment Instruments by Evaluation Experts II

\begin{tabular}{|c|c|c|c|}
\hline No & Component / Indicator & Average & Criteria \\
\hline & $\begin{array}{l}\text { A. Conformity of material with basic } \\
\text { competencies }\end{array}$ & $88 \%$ & Very Good \\
\hline 1 & $\begin{array}{l}\text { The material in the authentic assessment instrument } \\
\text { is in accordance with the specified SK and KD }\end{array}$ & $100 \%$ & Very Good \\
\hline 2 & $\begin{array}{l}\text { Material relevant to competencies that must be } \\
\text { mastered by students }\end{array}$ & $100 \%$ & Very Good \\
\hline 3 & $\begin{array}{l}\text { The accuracy of the unit title with the description } \\
\text { of the material in each section }\end{array}$ & $75 \%$ & Good \\
\hline \multirow[t]{2}{*}{4} & $\begin{array}{l}\text { The level of difficulty and complexity of the } \\
\text { material is adjusted to students' thinking abilities }\end{array}$ & $75 \%$ & Good \\
\hline & $\begin{array}{l}\text { B. Presenting competencies that must be } \\
\text { mastered by students }\end{array}$ & $75 \%$ & Good \\
\hline 5 & $\begin{array}{l}\text { Competencies to be achieved are presented in } \\
\text { authentic assessment instruments }\end{array}$ & $75 \%$ & Good \\
\hline \multirow[t]{2}{*}{6} & Accuracy of learning objectives & $75 \%$ & Good \\
\hline & C. Material accuracy & $88 \%$ & Very Good \\
\hline 7 & $\begin{array}{l}\text { The material presented is in accordance with } \\
\text { scientific truth }\end{array}$ & $75 \%$ & Good \\
\hline 8 & $\begin{array}{l}\text { The depth of material is in accordance with the } \\
\text { level of development of students }\end{array}$ & $75 \%$ & Good \\
\hline 9 & $\begin{array}{l}\text { Conformity between basic competencies and } \\
\text { learning objectives }\end{array}$ & $100 \%$ & Very Good \\
\hline \multirow[t]{2}{*}{10} & $\begin{array}{l}\text { Appropriateness of grading assessment with the } \\
\text { type of assessment of skill aspects in each sub- } \\
\text { theme (demanding deed tests) }\end{array}$ & $100 \%$ & Very Good \\
\hline & D. Authentic Assessment & $93 \%$ & Very Good \\
\hline 11 & $\begin{array}{l}\text { Appropriate assessment in measuring attitude } \\
\text { competency }\end{array}$ & $75 \%$ & Good \\
\hline 12 & $\begin{array}{l}\text { Appropriate assessment in measuring knowledge } \\
\text { competencies }\end{array}$ & $75 \%$ & Good \\
\hline 13 & $\begin{array}{l}\text { Appropriate assessment in measuring skill } \\
\text { competency }\end{array}$ & $100 \%$ & Very Good \\
\hline 14 & Assessment encourages students to think critically. & $75 \%$ & Good \\
\hline 15 & $\begin{array}{l}\text { Assessment instruments can collect all student } \\
\text { assessment data on drama text learning material. }\end{array}$ & $100 \%$ & Very Good \\
\hline 16 & $\begin{array}{l}\text { Assessment instruments can be carried out during } \\
\text { the learning process. }\end{array}$ & $100 \%$ & Very Good \\
\hline 17 & $\begin{array}{l}\text { Assessment instruments access understanding and } \\
\text { critical thinking }\end{array}$ & $100 \%$ & Very Good \\
\hline 18 & $\begin{array}{l}\text { Assessment instruments are relevant to basic } \\
\text { competencies and core competencies }\end{array}$ & $100 \%$ & Very Good \\
\hline
\end{tabular}




\begin{tabular}{|l|l|l|l|}
\cline { 2 - 4 } 19 & $\begin{array}{l}\text { Instrument for assessment in accordance with the } \\
\text { material taught }\end{array}$ & $100 \%$ & Very Good \\
\hline 20 & $\begin{array}{l}\text { The assessment is consistent with having accurate } \\
\text { scoring guidelines }\end{array}$ & $100 \%$ & Very Good \\
\hline Average Amount of All Sub Components & $\mathbf{8 6 \%}$ & Very Good \\
\hline
\end{tabular}

Table 12. The Percentage of Assessment for Each Sub Component of Evaluation Expert I

\begin{tabular}{|l|l|l|l|}
\hline No & Sub Component & Average (\%) & Criteria \\
\hline 1 & $\begin{array}{l}\text { Compatibility of material with } \\
\text { basic competencies }\end{array}$ & $88 \%$ & Very Good \\
\hline 2 & $\begin{array}{l}\text { Presenting competencies that must } \\
\text { be mastered by students }\end{array}$ & $75 \%$ & Good \\
\hline 3 & Material accuracy & $88 \%$ & Very Good \\
\hline 4 & Authentic assessment & $93 \%$ & Very Good \\
\hline Average & $\mathbf{8 6 \%}$ & Very Good \\
\hline
\end{tabular}

Table 13. The Percentage of Assessment of Item Description Form Test Instruments from Evaluation Experts I and II.

\begin{tabular}{|c|c|c|c|c|c|c|}
\hline \multirow[b]{2}{*}{ No } & \multirow[b]{2}{*}{ Sub Component } & \multicolumn{2}{|c|}{ Respondent } & \multirow{2}{*}{$\begin{array}{l}\text { Total } \\
\text { score }\end{array}$} & \multirow{2}{*}{$\begin{array}{l}\text { Average } \\
(\%)\end{array}$} & \multirow[b]{2}{*}{ Criteria } \\
\hline & & 1 & 2 & & & \\
\hline 1 & $\begin{array}{l}\text { Compatibility of } \\
\text { material with basic } \\
\text { competencies }\end{array}$ & 15 & 14 & 29 & $91 \%$ & Very Good \\
\hline 2 & $\begin{array}{l}\text { Presenting } \\
\text { competencies that } \\
\text { must be mastered by } \\
\text { students }\end{array}$ & 7 & 6 & 13 & $81,25 \%$ & Very Good \\
\hline 3 & Material accuracy & 15 & 14 & 29 & $90,63 \%$ & Very Good \\
\hline 4 & Authentic assessment & 36 & 37 & 73 & $91,25 \%$ & Very Good \\
\hline \multicolumn{2}{|c|}{ Average } & 73 & 71 & 144 & $89 \%$ & Very Good \\
\hline
\end{tabular}

The results of the validation of expert evaluations I and II for the assessment instruments in the sub-component of material suitability with basic competencies had an average percentage of $91 \%$ with the criteria of "very good". The results of the validation of expert evaluations I and II in the sub-component present the competencies that must be mastered by students have an average percentage of $81.25 \%$ with the criteria of "very good". The results of the validation of expert evaluations I and II on the sub-component of material accuracy have an average percentage of $90.63 \%$ with the criteria of "very good". The validation results of expert evaluations I and II in the sub-component of authentic assessment have an average percentage of $91.25 \%$ with the criteria of "very good". The average percentage of all sub- 
components by evaluation experts I and II is $89 \%$ with the criteria of "very good". This means that the authentic assessment instrument for drama text learning developed has good quality. Therefore, an authentic assessment instrument for drama text learning is worthy of being tested in the field.

Table 14. Data on Indonesian Language Teacher Assessment of Authentic Assessment Instruments on Drama Text Learning

\begin{tabular}{|l|l|l|l|}
\hline No & Indicator / Statement & Average & Criteria \\
\hline 1 & $\begin{array}{l}\text { The overall appearance of the assessment } \\
\text { instrument is interesting }\end{array}$ & $83,33 \%$ & Very Good \\
\hline 2 & $\begin{array}{l}\text { The language used in the assessment instrument can } \\
\text { be understood }\end{array}$ & $91,66 \%$ & Very Good \\
\hline 3 & $\begin{array}{l}\text { The presentation of material in the assessment } \\
\text { instrument is arranged systematically }\end{array}$ & $75 \%$ & Good \\
\hline 4 & $\begin{array}{l}\text { Materials with assessment instruments are in } \\
\text { accordance with the learning objectives }\end{array}$ & $100 \%$ & Very Good \\
\hline 5 & $\begin{array}{l}\text { The authentic domain has been explained in the } \\
\text { assessment instrument developed }\end{array}$ & $91,66 \%$ & Very Good \\
\hline 6 & $\begin{array}{l}\text { Assessment in assessment instruments helps } \\
\text { teachers to evaluate students more deeply }\end{array}$ & $91,66 \%$ & Very Good \\
\hline 7 & $\begin{array}{l}\text { Questions in the assessment instrument can } \\
\text { stimulate critical thinking skills }\end{array}$ & $91,66 \%$ & Very Good \\
\hline 8 & $\begin{array}{l}\text { The types of assignments in assessment instruments } \\
\text { vary }\end{array}$ & $91,66 \%$ & Very Good \\
\hline 9 & $\begin{array}{l}\text { Latest information in assessment instruments in } \\
\text { accordance with the development of science and } \\
\text { technology }\end{array}$ & $83,33 \%$ & Very Good \\
\hline 10 & $\begin{array}{l}\text { The assessment instrument helps students } \\
\text { understand drama text material }\end{array}$ & $100 \%$ & Very Good \\
\hline 11 & $\begin{array}{l}\text { Appraisal instruments differ from previous } \\
\text { assessment instruments }\end{array}$ & $100 \%$ & Very Good \\
\hline 12 & $\begin{array}{l}\text { The instrument of assessment can be used by the } \\
\text { teacher well }\end{array}$ & $100 \%$ & Very Good \\
\hline 13 & $\begin{array}{l}\text { Assessment instruments train students to enrich } \\
\text { students' knowledge }\end{array}$ & $91,66 \%$ & Very Good \\
\hline 14 & $\begin{array}{l}\text { Assessment instruments make it easier for students } \\
\text { to express their opinions in oral or written form }\end{array}$ & $91,66 \%$ & Very Good \\
\hline 15 & $\begin{array}{l}\text { The assessment instrument makes it easier for } \\
\text { students to deduce drama text material }\end{array}$ & $91,66 \%$ & Very Good \\
\hline & $\begin{array}{l}\text { Average Amount } \\
\text { Ind }\end{array}$ & Very Good \\
\hline
\end{tabular}


Table 15. Individual Trial Data (3 students)

\begin{tabular}{|c|c|c|c|}
\hline No & Indicator / Statement & Average & Criteria \\
\hline \multicolumn{2}{|c|}{ Material } & $75 \%$ & Good \\
\hline 1 & $\begin{array}{l}\text { This assessment instrument makes me happy to } \\
\text { learn }\end{array}$ & $58,33 \%$ & Fair \\
\hline 2 & $\begin{array}{l}\text { The presentation of the text in the assessment } \\
\text { instrument starts from the easy to the difficult and } \\
\text { from the concrete to the abstract }\end{array}$ & $75 \%$ & Good \\
\hline 3 & $\begin{array}{l}\text { This assessment instrument contains questions that } \\
\text { encourage me to think critically }\end{array}$ & $83,33 \%$ & $\begin{array}{l}\text { Very } \\
\text { Good }\end{array}$ \\
\hline 4 & $\begin{array}{l}\text { The presentation of the text in this assessment } \\
\text { instrument encouraged me to be able to answer the } \\
\text { test questions used }\end{array}$ & $83,33 \%$ & $\begin{array}{l}\text { Very } \\
\text { Good }\end{array}$ \\
\hline 5 & $\begin{array}{|lll|}\begin{array}{l}\text { This assessment instrument encouraged my } \\
\text { curiosity }\end{array} & & \\
\end{array}$ & $66,67 \%$ & Fair \\
\hline 6 & $\begin{array}{l}\text { This assessment instrument contains multiple } \\
\text { choice tests and descriptions that can test how far } \\
\text { my understanding of drama texts is }\end{array}$ & $83,33 \%$ & $\begin{array}{l}\text { Very } \\
\text { Good }\end{array}$ \\
\hline \multicolumn{2}{|c|}{ Language } & $75 \%$ & Good \\
\hline 7 & The language used is simple and easy to understand & $75 \%$ & Good \\
\hline 8 & The letters used are simple and easy to read & $75 \%$ & Good \\
\hline \multicolumn{2}{|c|}{ Interest } & $68,75 \%$ & Fair \\
\hline 9 & $\begin{array}{l}\text { Using this assessment instrument makes my } \\
\text { learning more focused and coherent }\end{array}$ & $75 \%$ & Good \\
\hline 10 & $\begin{array}{l}\text { Using this assessment instrument can increase } \\
\text { motivation to learn }\end{array}$ & $66,67 \%$ & Fair \\
\hline 11 & $\begin{array}{l}\text { Using this assessment instrument can make learning } \\
\text { drama text material fun }\end{array}$ & $75 \%$ & Good \\
\hline \multicolumn{2}{|c|}{ Average Amount } & $75,39 \%$ & Good \\
\hline
\end{tabular}

Table 16. Obtaining Individual Test Scores (3 students)

\begin{tabular}{|l|l|l|l|}
\hline No & Assessment Indicator & Average (\%) & Criteria \\
\hline 1 & Material & $75 \%$ & Good \\
\hline 2 & Language & $75 \%$ & Good \\
\hline 3 & Interest & $68,75 \%$ & Fair \\
\hline Average & $\mathbf{7 5 , 3 9 \%}$ & Good \\
\hline
\end{tabular}


Table 17. Small Group Trial Data (9 students)

\begin{tabular}{|c|c|c|c|}
\hline No & Indicator / Statement & Average & Criteria \\
\hline \multicolumn{2}{|c|}{ Material } & $82,35 \%$ & Very Good \\
\hline 1 & $\begin{array}{l}\text { This assessment instrument makes me happy to } \\
\text { learn }\end{array}$ & $80,56 \%$ & Good \\
\hline 2 & $\begin{array}{l}\text { The presentation of the text in the assessment } \\
\text { instrument starts from the easy to the difficult and } \\
\text { from the concrete to the abstract }\end{array}$ & $77,78 \%$ & Good \\
\hline 3 & $\begin{array}{l}\text { This assessment instrument contains questions that } \\
\text { encourage me to think critically }\end{array}$ & $86 \%$ & Very Good \\
\hline 4 & $\begin{array}{l}\text { The presentation of the text in this assessment } \\
\text { instrument encouraged me to be able to answer the } \\
\text { test questions used }\end{array}$ & $86 \%$ & Very Good \\
\hline 5 & $\begin{array}{l}\begin{array}{l}\text { This assessment instrument encouraged my } \\
\text { curiosity }\end{array} \\
\end{array}$ & $77,78 \%$ & Good \\
\hline 6 & $\begin{array}{l}\text { This assessment instrument contains multiple } \\
\text { choice tests and descriptions that can test how far } \\
\text { my understanding of drama texts is }\end{array}$ & $86 \%$ & Very Good \\
\hline \multicolumn{2}{|c|}{ Language } & $82 \%$ & Very Good \\
\hline 7 & The language used is simple and easy to understand & $86 \%$ & Very Good \\
\hline 8 & The letters used are simple and easy to read & $77,78 \%$ & Good \\
\hline \multicolumn{2}{|c|}{ Interest } & $78,71 \%$ & Good \\
\hline 9 & $\begin{array}{l}\text { Using this assessment instrument makes my } \\
\text { learning more focused and coherent }\end{array}$ & $77,78 \%$ & Good \\
\hline 10 & $\begin{array}{l}\text { Using this assessment instrument can increase } \\
\text { motivation to learn }\end{array}$ & $80,56 \%$ & Good \\
\hline 11 & $\begin{array}{l}\text { Using this assessment instrument can make learning } \\
\text { drama text material fun }\end{array}$ & $77,78 \%$ & Good \\
\hline \multicolumn{2}{|c|}{ Average Amount } & $81 \%$ & Very Good \\
\hline
\end{tabular}

Table 18. Obtaining Small Group Trial Scores (9 students)

\begin{tabular}{|l|l|l|l|}
\hline No & Assessment Indicator & Average (\%) & Criteria \\
\hline 1 & Material & $82,35 \%$ & Very Good \\
\hline 2 & Language & $82 \%$ & Very Good \\
\hline 3 & Interest & $78,71 \%$ & Good \\
\hline Average & $\mathbf{8 1 \%}$ & Very Good \\
\hline
\end{tabular}


Table 19. Limited Field Student Test Data (32 students)

\begin{tabular}{|c|c|c|c|}
\hline No & Indicator / Statement & Average & Criteria \\
\hline \multicolumn{2}{|c|}{ Material } & $91,14 \%$ & Very Good \\
\hline 1 & $\begin{array}{l}\text { This assessment instrument makes me happy to } \\
\text { learn }\end{array}$ & $83,59 \%$ & Very Good \\
\hline 2 & $\begin{array}{l}\text { The presentation of the text in the assessment } \\
\text { instrument starts from the easy to the difficult and } \\
\text { from the concrete to the abstract }\end{array}$ & $89,84 \%$ & Very Good \\
\hline 3 & $\begin{array}{l}\text { This assessment instrument contains questions that } \\
\text { encourage me to think critically }\end{array}$ & $87,5 \%$ & Very Good \\
\hline 4 & $\begin{array}{l}\text { The presentation of the text in this assessment } \\
\text { instrument encouraged me to be able to answer the } \\
\text { test questions used }\end{array}$ & $96,87 \%$ & Very Good \\
\hline 5 & \begin{tabular}{|lll}
$\begin{array}{l}\text { This assessment instrument encouraged my } \\
\text { curiosity }\end{array}$ & & \\
\end{tabular} & $94,53 \%$ & Very Good \\
\hline 6 & $\begin{array}{l}\text { This assessment instrument contains multiple } \\
\text { choice tests and descriptions that can test how far } \\
\text { my understanding of drama texts is }\end{array}$ & $94,53 \%$ & Very Good \\
\hline \multicolumn{2}{|c|}{ Language } & $94,53 \%$ & Very Good \\
\hline 7 & The language used is simple and easy to understand & $95,31 \%$ & Very Good \\
\hline 8 & The letters used are simple and easy to read & $93,75 \%$ & Very Good \\
\hline \multicolumn{2}{|c|}{ Interest } & $92,45 \%$ & Very Good \\
\hline 9 & $\begin{array}{l}\text { Using this assessment instrument makes my } \\
\text { learning more focused and coherent }\end{array}$ & $93,75 \%$ & Very Good \\
\hline 10 & $\begin{array}{l}\text { Using this assessment instrument can increase } \\
\text { motivation to learn }\end{array}$ & $93,75 \%$ & Very Good \\
\hline 11 & $\begin{array}{l}\text { Using this assessment instrument can make learning } \\
\text { drama text material fun }\end{array}$ & $89,84 \%$ & Very Good \\
\hline \multicolumn{2}{|c|}{ Average Amount } & $92,71 \%$ & Very Good \\
\hline
\end{tabular}

Table 20. Percentage of Obtaining Limited Field Test Scores (32 students)

\begin{tabular}{|l|l|l|l|}
\hline No & Assessment Indicator & Average (\%) & Criteria \\
\hline 1 & Material & $91,14 \%$ & Very Good \\
\hline 2 & Language & $94,53 \%$ & Very Good \\
\hline 3 & Interest & $92,45 \%$ & Very Good \\
\hline Average & $\mathbf{9 2 , 7 1 \%}$ & Very Good \\
\hline
\end{tabular}




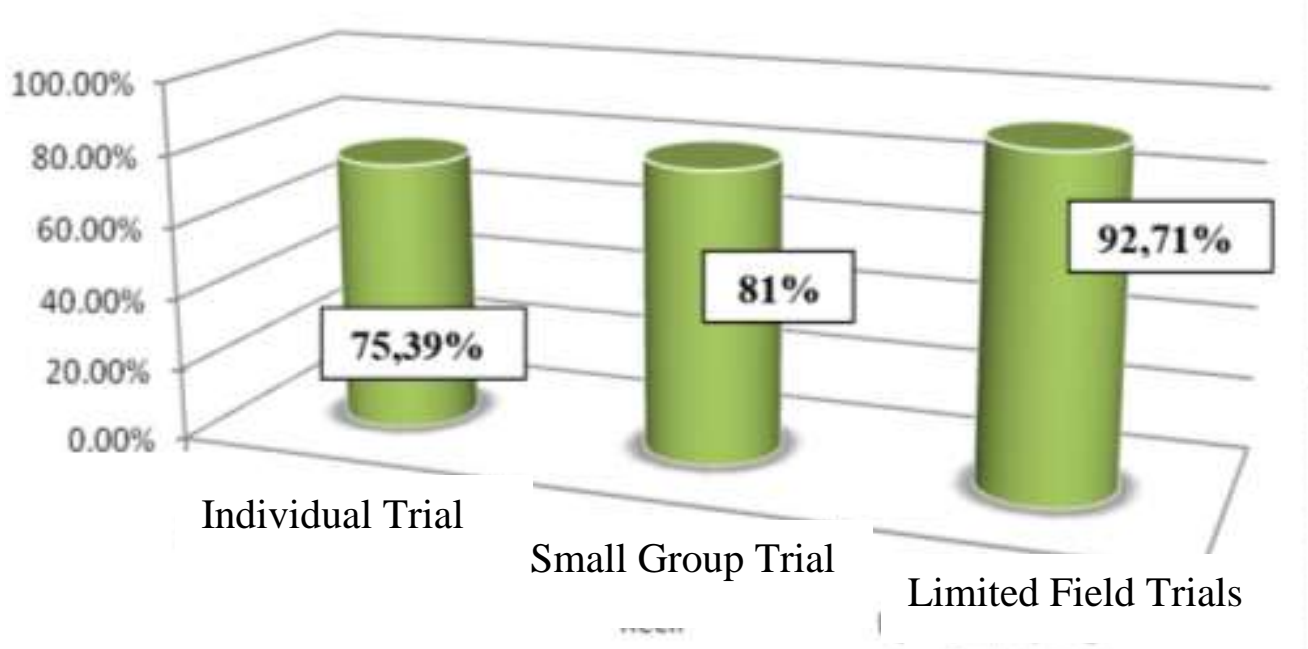

Figure 6. Results of Student Assessment of Application of Așiesstônênt Instruments

\section{Conclusion}

The quality of authentic assessment instruments on drama text learning is obtained from the results of validation and assessment given by material experts, evaluation experts, teacher responses, and student responses. Based on the assessment of the design experts, evaluation experts, Indonesian language teacher assessment, and student responses. The product is known to have good quality and is worth after using the validity analysis of the product using the Sugiyono formula, then the classification of scores in the form of percentages is interpreted with qualitative sentences. The product is said to be worth for use when it reaches a score of $61 \% \leq X<80 \%$ with the criteria of "good" and a score of $81 \% \leq X<100 \%$ with the criteria of "very good". The product is feasible to use if it is in the criteria of "good" and "very good" with a note "without any revisions". The average percentage of all sub-components from the results of validation of design experts I and II is $81 \%$ with the criteria of "very good". The average percentage of all sub-components from the validation of material experts I and II is $88.83 \%$ with the criteria of "very good". The average percentage of all sub-components by evaluation experts I and II is $89 \%$ with the criteria of "very good". The results of the teacher's response to the authentic assessment instruments in drama text learning developed have an average percentage of $91.66 \%$ with the criteria of "very good". The results of student responses to the assessment instrument obtained the average percentage of the overall limited field test was $92.71 \%$ with the criteria of "very good".

The level of students' ability to answer drama text questions was obtained from the trials conducted by giving pretest and posttest to class VIII students of Junior High Scool 6 Tebing Tinggi, which amounted 32 students. The lowest value of students seen from the results of the pretest was 52 and the highest was 82. The average value of the student's pretest was 68.56. Based on the average value of the student pretest data above, it can be concluded that the ability of students does not experience a significant high increase and has not reached KKM. Learning by using authentic assessment instruments on drama text learning gained an average of 80.97. The lowest student score is 70 and the highest was 98 . Based on the average value of student posttest data above, it can be concluded that the ability of students to experience a significant 
increase was high and reaches KKM as expected. The effectiveness of the assessment instrument developed was $80.97 \%$ and the effectiveness before using the valuation instrument was $68.56 \%$. Therefore, the level of students' ability to answer drama text questions increases after the product of authentic assessment instruments in drama text learning was applied in learning.

\section{References}

Amelia Hani Saputri. 2016. Pelaksanaan Penilaian Autentik Kurikulum 2013 dalam Pembelajaran Seni Tari di SMP Negeri 1 Labuhan Ratu Lampung Timur. (Skripsi). Universitas Lampung.

Arikunto, S. 2013. Dasar-dasar Evaluasi Pendidikan. Jakarta: Bumi Aksara.

Arikunto, Suharsimi . 2014. Dasar-Dasar Evaluasi Pendidikan. Jakarta: Bumi Aksara.

Asrul et al. 2015. Evaluasi Pembelajaran. Bandung: Citapustaka Media.

Borg and Gall.2003. Educational Research, An Introduction. New York and London. Longman Inc

Bowo, Sigit Ari and Hariyadi. 2015. Penilaian Autentik Materi Sastra Pada Kurikulum 2013 Sebagai Upaya Menyongsong MEA. Seminar Nasional Pendidikan Bahasa Indonesia.

Endraswara. 2011. Metode Pembelajaran Drama Apresiasi, Ekspresi dan Pengkajian). Yogyakarta: CAPS.

Fadliyatis, Kukuh S, Titik Harsiati, Muakibatul Hasanah. 2016. "Pengembangan Instrumen Asesmen Autentik Ketrampilan Menulis Teks Cerpen dan Teks Fabel untuk Siswa SMP/MTs yang Mengimplementasikan Kurikulum 2013”. Jurnal Pendidikan: Teori, Penelitian,danPengembangan Vol 1 No. 3.

Florensy, Angla Sauhenda, Titik Harsiati, Martutik. 2016. "Pengembangan Asesmen Penugasan Menulis Teks Ekposisi dengan Rangsangan Masalah Autentik". Jurnal Pendidikan: Teori, Penelitian dan Pengembangan. Vol. 1 No. 3.

Herrington, J. \& Oliver, R. (2000). An Instructional Design Framework for Authentic Learning Environments. Educational Technology Research and Development, 48(3), 23-48.

I Gusti Ayu Komang Lili Absari, et al. 2015. Penilaian Autentik Guru Bahasa Indonesia dalam Pembelajaran Menulis Siswa Kelas VII Di SMP Negeri $1 \quad$ Singaraja. eJournal Universitas Pendidikan Ganesha: Vol 3 No. 1.

Johannes, Berkat Pakpahan. 2016. Pengaruh strategi pembelajaran dan motivasi belajar terhadap kemampuan memahami unsur intrinsik drama siswa kelas VIII SMP Swasta Parulian 2 Medan (Tesis).

Kunandar. 2014. Penilaian Autentik (Penilaian Hasil Belajar Peserta Didik Berdasarkan K13). Jakarta : Grafindo.

Mansyur et.al. 2015. Asesmen Pembelajaran di Sekolah Panduan bagi Guru dan Calon Guru. Yogyakarta: Pustaka Pelajar

Muhlis Fajar Wicaksana, et al. Potret Kualitas dan Kebutuhan Pengembangan Model Penilaian Autentik (Authentic Assesment)Pembelajaran Bahasa Indonesia Di SMP. Konferensi Nasional Bahasa dan Sastra III.

Newmann, Fred M, M. Bruce King, and Dana L. Carmichael. 2007. Authentic Instruction and Assessment. Lowa : Departement of Education.

Nurdin, Syafruddin, Adriantoni. 2016. Kurikulum Pembelajaran. Depok : Rajawali Pers. 
Nurgiantoro. 2011. Penilaian Otentik. Yogyakarta: UGM Press.

Permendikbud No. 66 tahun 2013 tentang Standar Penilaian Pendidikan

Purnamasari, Dewi Ayu, Iqbal Hilal, Ali Mustofa. 2015. "Pengembangan Instrumen

Penilaian Tertulis untuk Pembelajaran Teks Eksposisi di SMA”. Jurnal Kata (Bahasa, Sastra, dan Pembelajarannya). Vol. $1 \quad$ No. 1

Purwanto. 2009. Evaluasi Hasil Belajar. Surakarta: Pustaka Belajar.

Pratiwi,Yuni and Frida Siswiyaanti. 2014. Teori Drama dan Pembelajarannya. Yogyakarta: Ombak.

Priyanti, Dwi. 2017. Pengembangan Penilaian Autentik Aspek Keterampilan di Kelas IV SD (Tesis)

Ratnawulan, Elis and Rusdiana, A. 2014. Evaluasi Pembelajaran Dengan Pendekatan Kurikulum 2013.Bandung : Pustaka Setia.

Rosmawaty. 2011. Seni Drama. Medan: UNIMED.

Satrianingsi. 2016. Penerapan Model Pembelajaran Kooperatif Tipe Team Assisted Individualization untuk Meningkatkan Hasil Belajar Menulis Kreatif Naskah Drama

Satu Babak Siswa Kelas VIII Mts. Swasta Labibia. Jurnal Humatika: Vol 1 No. 16

Sani, Ridwan Abdullah. 2016. Penilaian Autentik. Jakarta : Bumi Aksara.

Sudijono, Anas. 2013. Pengantar Evaluasi Pendidikan. Jakarta: Rajagrafindo Persada.

Sugiyono. 2015. Metode Penelitian Pendidikan. Bandung: Alfabeta.

Supardi. 2015. Penilaian Autentik: Pembelajaran Afektif, Kognitif, dan Psikomotorik

(Konsep dan Aplikasi). Jakarta: PT Raja Grafindo Persada.

Supryadi. 2013. Evaluasi Pembelajaran Bahasa Indonesia. Gorontalo : UNG Press.

Suroso. 2015. Drama: Teori dan Praktik Pementasan. Yogyakarta: ELMATERA.

San, Suyadi. 2015. Drama: Konsep Teori dan Kajian. Medan: CV Partama Mitra Sari.

Tegeh, Made et al. 2014. Model Penelitian Pengembangan. Yogyakarta: Graha Ilmu.

Trianto. 2010. Mengembangkan Model Pembelajaran Tematik, Jakarta: PT Prestasi Pustaka.

Uno, Hamzah B, Satria. 2014. Assessment Pembelajaran . Jakarta : Bumi Aksara.

Wolbers Kimberly, et al. 2015. The Writing Performance of Elementary Students Receiving

Strategic and Interactive Writing Instruction". Advance Access Publication June 21.

Kizlik, Bob. 2009. Measurement, Assessment, and Evaluation in Education.

Overton, Terry. 2008. Assessing Learners with Special Needs: An Applied Approach ( $7^{\text {th }}$ Edition). University of Texas - Brownsville 